\title{
PENGEMBANGAN MODEL PEMBELAJARAN PROBLEM SOLVING BERBASIS VIDEO TERHADAP METAKOGNISI DAN PEMAHAMAN KONSEP FISIKA
}

\author{
Mariati Purnama Simanjuntak \\ Program Studi Pendidikan Fisika Unimed \\ mariatips@yahoo.co.id
}

\begin{abstract}
Abstrak. Dikembangkan model pembelajaran fisika berbasis masalah. Model ini dikembangkan dengan menggunakan metode research \& development $(\mathrm{R}$ \& D). Model pembelajaran problem solving yang berhasil dikembangkan dengan fase-fase pembelajaran, yaitu: mengorientasikan mahasiswa pada masalah; mengorganisasi mahasiswa untuk belajar; membimbing penyelidikan individu dan kelompok; mengembangkan dan menyajikan hasil penyelidikan; dan penguatan dan refleksi. Subyek penelitian adalah mahasiswa pendidikan fisika di salah satu perguruan tinggi di Medan pada tahun akademik 2010/2011 yang terdiri dari 25 mahasiswa. Metode yang digunakan dalam ujicoba terbatas adalah penelitian pra-eksperimen dengan desain one group pretest- posttest control group design. Data metakognisi dikumpulkan dengan tes berbentuk uraian dan data pemahaman konsep dikumpulkan dengan tes pilihan ganda. Data dianalisis dengan menggunakan skor gain dinormalisasi, $\mathrm{N}$-gain. Hasil penelitian ini menunjukkan bahwa model pembelajaran problem solving dapat meningkatkan metakognisi dan pemahaman konsep pada topik Kinematika dan Dinamika dalam kategori sedang.
\end{abstract}

Kata kunci: model pembelajaran problem solving, metakognisi, pemahaman konsep

\section{DEPELOVING LEARNING MODELS PROBLEMS SOLVING VIDEO BASED TO METACOGNITION AND PHYSICS CONCEPT UNDERSTANDING}

\author{
Mariati Purnama Simanjuntak \\ Physics Education Program-State University of Medan \\ mariatips@yahoo.co.id
}

\begin{abstract}
We have developed a problem solving based physics learning model. This model was developed by using ( $R \& D$ ) method including by $4-D$ steps, they are define, design, develop and disseminate. The problem solving based learning which is successful to develop indentified with learning phases, including: orientation of students on problem; organization of students for study; investigation guides individual and group, developing and presentation of the result of investigation; and reflection and reinforcement. The research subjects are physics education students at one of the universities in Medan in the academic year of 2010/2011 that consist of 25 students. Method that used research is pre-experimental with one group pretest-posttest design. The metacognition data were collected by essay test and conceptual understanding
\end{abstract}


data were collected by multiple-choice test. Data were analyzeds by using normalized gain scores, $N$-gain. Results of this research show that: problem solving based learning model cane enhance students' metacognition and conceptual understanding of particle kinematics and dynamics topics in midle category.

Keywords: problem solving based learning model, metacognition, conceptual understanding

\section{PENDAHULUAN}

Meningkatkan mutu pendidikan merupakan tanggung jawab semua pihak yang terlibat dalam pendidikan, termasuk dosen di tingkat perguruan tinggi. Dosen hendaknya menggunakan berbagai pendekatan, strategi, metode dan model pembelajaran dalam setiap pembelajaran yang dapat memudahkan mahasiswa memahami materi yang diajarkan. Untuk itu dosen perlu meningkatkan mutu pembelajarannya, dimulai dengan rancangan pembelajaran yang baik dengan memperhatikan tujuan, karakteristik mahasiswa, materi yang diajarkan, dan sumber belajar yang tersedia. Kenyataannya masih banyak ditemui proses pembelajaran yang kurang berkualitas, tidak efisien dan kurang mempunyai daya tarik, bahkan cenderung membosankan, sehingga hasil belajar yang dicapai tidak optimal. Hal ini juga terjadi di salah satu perguruan tinggi negeri di Sumatera Utara, khususnya dalam perkuliahan Fisika Umum.

Fisika Umum sebagai salah satu mata kuliah wajib bagi mahasiswa calon guru fisika di LPTK dan matakuliah yang diberikan di semester pertama karena matakuliah tersebut merupakan syarat untuk melanjutkan pada jenjang matakuliah selanjutnya. Mata kuliah ini juga mendasari pengembangan rekayasa, desain, perencanaan, teknologi dan mempunyai peran penting dalam berbagai disiplin serta mengembangkan daya pikir manusia. Namun demikian, Fisika Umum merupakan salah satu mata kuliah yang dianggap sulit oleh mahasiswa. Hal ini dikarenakan Fisika Umum membutuhkan matematika yang rumit (Nashon, dalam Campbell, 2007); Materi yang terlalu banyak, hanya bergantung pada buku teks, abstrak dan kompleks (Sheppard \& Robin, dalam Campbell, 2007); Membutuhkan kegiatan laboratorium (Heller \& Heller, 1999); dan sering terjadi miskonsepsi (Anderson \& Nashon, 2006).

Berdasarkan hasil pengamatan di lapangan pada salah satu perguruan tinggi di Medan, terdapat kecenderungan proses belajar mengajar di kelas bersifat analitis, dengan menitik-beratkan pada penurunan rumus-rumus fisika melalui analisis matematis, mahasiswa berusaha menghapal rumus namun kurang memaknai untuk apa dan bagaimana rumus itu digunakan. Masalah yang diberikan dosen berupa soal-soal yang lebih menekankan pada manipulasi matematis, bukan masalah yang ada dalam kehidupan sehari-hari sehingga pembelajaran Fisika Umum menjadi kurang bermakna bagi mahasiswa itu sendiri.

Dosen LPTK sebagai salah satu yang berperan dalam meningkatkan mutu pendidikan terhadap calon guru, maka dosen dituntut untuk dapat memadukan pengetahuan konten dan pengetahuan pedagogis (pedagogical conten knowledge, (PCK)) dalam pembelajaran karena mahasiswa akan lebih mudah belajar dan mencontoh apa yang dialaminya daripada membuat sendiri. Pengalaman langsung yang diperoleh akan mereka terapkan dan kembangkan di lapangan ketika mereka sudah menjadi guru. Hal ini sesuai dengan Permendiknas nomor 16 tahun 2007 tentang standar kompetensi profesional, salah satunya guru harus kreatif dan inovatif dalam penerapan dan pengembangan bidang ilmu fisika dan ilmuilmu terkait. Kompetensi ini dielaborasi lebih lanjut dalam Permendiknas nomor 41 tahun 
2007 tentang standar proses, bahwa dalam kegiatan elaborasi, dosen memberikan kesempatan kepada peserta didik untuk dapat memahami, merancang, mengetahui bagaimana cara dan mengapa melakukan, memecahkan masalah, menganalisis, mengevaluasi, dan mengembangkan pemahaman konsepnya. Standar tersebut menunjukkan pentingnya kemampuan metakognisi dikembangkan.

Metakognisi adalah pengetahuan, kesadaran, dan kendali atas proses kognisi (Flavel, dalam Matlin, 2009; Anderson et al., 2001). Simon (dalam Desoete et al., 2001) membagi metakognisi menjadi dua komponen, yaitu: pengetahuan dan keterampilan metakognisi. Pengetahuan metakognisi didefinisikan sebagai pengetahuan dan pemahaman pada proses berpikir. Keterampilan metakognisi didefinisikan sebagai pengendalian pada proses berpikir. Tiga komponen pengetahuan metakognisi: deklarasi, prosedural dan kondisional. Empat komponen keterampilan metakognisi: memprediksi, merencanakan, memonitor dan mengevaluasi.

Metakognisi dapat dibangun ketika mahasiswa melaksanakan pemecahan masalah (problem solving). Saat melaksanakan problem solving, kesadaran kognisi mahasiswa dapat ditumbuhkan karena memberikan arahan agar mahasiswa bertanya pada dirinya apakah memahami apa yang sedang mereka pelajari atau pikirkan. Mahasiswa dipandu untuk dapat menyadari apa yang diketahui dan apa yang tidak diketahui serta bagaimana pemecahan masalahnya, membuat perencanaan pendekatan pemecahan masalah, membuat tahap-tahap pemecahannya, memberi alasan mengapa pemecahan masalahnya demikian, memonitor apa yang sedang dilakukan dan kemajuan ke arah tujuan saat melaksanakan rencana, dan mengevaluasi apa yang sudah dilakukan. Hal ini sesuai dengan Flavell (dalam Winert \& Kluwe, 1987) yang menyatakan bahwa pembelajaran melalui upaya penyadaran dan pengendalian proses berpikir mahasiswa melalui problem solving merupakan pembela- jaran dengan pengembangan metakognisi (Flavell, dalam Winert \& Kluwe, 1987).

Kemampuan metakognisi yang dimiliki memungkinkan mahasiswa dapat mengembangkan pemahaman konsep karena dengan metakognisi, mahasiswa dapat mengkonstruksi pengetahuan, mengaplikasikan konsep-konsep fisika, dan memperdalam konsep-konsep fisika sehingga melahirkan jawaban ilmiah yang merepresentasikan pemahaman. Pengembangan pemahaman dapat terjadi karena fisika menyediakan masalah-masalah kompleks yang dapat menantang mahasiswa menerapkan dan mengembangkan pemahaman. Hal ini sesuai dengan Hollingword dan Mc. Loughlin (2002) yang menyatakan bahwa: metakognisi yang dimiliki mahasiswa dapat membimbing mereka dalam menyusun lingkungan belajar dan memilih strategi untuk memperbaiki kinerja kognisi pada masa yang akan datang dan metakognisi yang dimiliki dapat meningkatkan hasil belajar, khususnya daya ingat dan pemahaman. Hal ini juga didukung oleh (Anderson \& Nashon, 2006) yang menyatakan bahwa kemampuan metakognisi yang dimiliki mahasiswa dapat meningkatkan kapasitas belajar yang penuh makna dan mempengaruhi untuk mengkonstruksi pemahaman.

Mencermati pentingnya metakognisi dan pemahaman konsep, sehingga problem solving layak dikembangkan, maka pada penelitian ini dikembangkan model pembelajaran problem solving berbasis video yang dapat meningkatkan metakognisi dan pemahaman konsep mahasiswa. Proses problem solving dalam konteks ini dilakukan melalui penyelidikan berbasis eksperimen dan masalah yang disajikan berupa masalah kontekstual. Mahasiswa memecahkan masalah dengan melakukan penyelidikan melalui eksperimen yang direkam dengan menggunakan video dan hasil rekaman dianalisis dengan bantuan software tracker.

Sintaks model pembelajaran Fisika Umum berbasis problem solving yang berhasil dikembangkan adalah mengorientasikan mahasiswa pada masalah; mengorganisasi mahasiswa untuk belajar; membimbing penyelidikan 
individu dan kelompok, mengembangkan dan menyajikan hasil penyelidikan; dan penguatan dan refleksi.

\section{METODE PENELITIAN}

Metode yang digunakan dalam pengembangan model pembelajaran Fisika Umum berbasis problem solving adalah research and development ( $\mathrm{R} \& \mathrm{D})$ melalui langkah-langkah 4-D, yaitu: define, design, develop and disseminate (Thiagarajan, et al., 1974). Prosedur penelitian dan pengembangan model pembelajaran prolem solving berbasis video pada tahap pendefinisian dilakukan dengan menganalisis kebutuhan dengan mengumpulkan berbagai informasi yang berkaitan dengan produk yang akan dikembangkan. Pengumpulan berbagai informasi ini dilakukan dengan studi pendahuluan melalui studi literatur dan studi lapangan. Studi literatur berkaitan dengan studi dokumen dan materi lainnya yang mendukung pembuatan rancangan produk. Studi literatur dilakukan untuk menganalisis kompetensi seorang guru fisika serta peran perkuliahan Fisika Umum, metakognisi, pemahaman konsep dan teori-teori serta temuan-temuan penelitian dasar untuk merancang draft pengembangan model pembelajaran prolem solving berbasis video. Hasilhasil yang diperoleh pada studi literatur dan studi lapangan digunakan sebagai bahan untuk merancang produk awal, berupa model pembelajaran prolem solving berbasis video dan perangkat pembelajaran yang mendukung model yang dikembangkan. Pengembangan produk dilakukan dengan validasi pakar, ujicoba terbatas dan ujicoba skala luas atau implementasi.

Metode yang digunakan dalam penelitian ujicoba terbatas adalah pra-eksperimental dengan desain one group pretest-posttest design dengan hanya mengambil satu kelompok eksperimen sebagai sampel, tanpa mengambil kelompok kontrol dengan alasan bahwa penelitian ini hanya melihat sejauh mana peningkatan kemampuan metakognisi dan pemahaman konsep mahasiswa melalui penerapan model pembelajaran problem solving tanpa harus membandingkannya dengan pembelajaran yang lain. Subyek penelitian adalah mahasiswa calon guru fisika, sebanyak 25 orang pada tahun ajaran 2010/2011 pada salah satu perguruan tinggi di Medan. Tes yang dikembangkan untuk mengukur metakognisi berbentuk uraian yang terdiri dari 15 butir untuk topik Kinematika Partikel dan 13 butir untuk topik Dinamika Partikel. Tes ini mencakup indikator-indikator metakognisi dalam komponen prediksi, perencanaan, pemonitoran, evaluasi, deklarasi, prosedural, dan kondisional (Brown, dalam Desoete et al., 2001). Tes yang dikembangkan untuk mengukur pemahaman konsep dalam bentuk pilihan berganda yang terdiri dari 40 butir untuk topik Kinematika Partikel dan 48 butir untuk topik Dinamika Partikel. Tes ini mencakup indikatorindikator pemahaman konsep dalam aspek menginterpretasi, mencontohkan, membandingkan, mengklasifikasi, menjelaskan, dan menyimpulkan (Anderson, et al., 2001).

Peningkatan metakognisi dan pemahaman konsep dalam penerapan pembelajaran problem solving ditentukan berdasarkan rerata skor gain yang dinormalisasi, N-gain. Tinggi rendahnya $\mathrm{N}$-gain dapat diklasifikasikan sebagai berikut: (1) jika $\mathrm{N}$-gain $>70 \%$, termasuk dalam kategori tinggi; (2) jika 30\% $\leq$ $\mathrm{N}$-gain $\leq 70 \%$, maka termasuk kategori sedang; dan (3) jika $\mathrm{N}$-gain < 30\%, maka termasuk dalam kategori rendah (Hake \& Richard, 2002). Paper ini memaparkan hasilhasil penelitian dalam pengembangan model pembelajaran problem solving berbasis video dalam tahap ujicoba terbatas.

\section{HASIL PENELITIAN DAN PEMBAHASAN
1. Peningkatan Metakognisi dengan Penerapan Model Pembelajaran Problem Solving

Nilai gain yang dinormalisasi, N-gain metakognisi pada topik Kinematika Partikel sebesar 59\% dan pada topik Dinamika Partikel sebesar $63 \%$ dan berada pada kategori sedang. Rerata skor tes awal, tes akhir dan $\% \mathrm{~N}$-gain 
metakognisi pada topik Kinematika dan Dinamika Partikel ditunjukkan pada Tabel 1. Secara kuantitas tampak bahwa penerapan model pembelajaran problem solving berbasis video pada topik Kinematika dan Dinamika Partikel dapat meningkatkan metakognisi mahasiswa.

Tabel 1. Perbandingan Rerata Skor Tes Awal, Tes Akhir dan \% N-gain Metakognisi

\begin{tabular}{lcccc}
\hline Topik & $\begin{array}{c}\text { Rerat } \\
\text { a skor } \\
\text { tes } \\
\text { awal }\end{array}$ & $\begin{array}{c}\text { Rerata } \\
\text { skor } \\
\text { tes } \\
\text { akhir }\end{array}$ & $\begin{array}{c}\text { N- } \\
\text { gain } \\
(\%)\end{array}$ & $\begin{array}{c}\text { kate- } \\
\text { gori }\end{array}$ \\
\hline Kinematika & 19,79 & 66,91 & 59 & sedang \\
\hline Dinamika & 16,57 & 69,15 & 63 & sedang \\
\hline
\end{tabular}

Ket: Skor maksimum $=100$

Gambar 1 menunjukkan perbandingan $\mathrm{N}$-gain metakognisi yang dijabarkan dalam indikator setiap komponen metakognisi, yang meliputi deklarasi, prosedural, kondisional, prediksi, perencanaan, pemonitoran dan evaluasi berturut-turut sebesar besarnya $56 \%$, $67 \%, 55 \%, 59 \%$, 66\%, 63\%, dan 50\%. Untuk topik Dinamika Partikel, N-gain metakognisi untuk setiap indikator yang meliputi deklarasi, prosedural, kondisional, prediksi, perencanaan, pemonitoran dan evaluasi secara berturut-turut sebesar $58 \%, 69 \%, 49 \%, 63 \%, 69 \%, 58 \%$, dan $59 \%$. Hal ini menunjukkan bahwa peningkatan $\mathrm{N}$-gain untuk semua indikator metakognisi termasuk kategori sedang.

Peningkatan N-gain metakognisi tertinggi pada indikator dalam komponen prosedural dan perencanaan pada topik Kinematika dan Dinamika Partikel. Hal ini dimungkinkan karena dalam tahap-tahap problem solving melalui eksperimen berbasis video, mahasiswa dituntut untuk dapat merencanakan apa yang akan dilakukan dalam penyelidikan melalui eksperimen dan mahasiswa didorong untuk berpikir tentang setiap tahap prosedural dan tujuan dari masing-masing tahap tersebut.

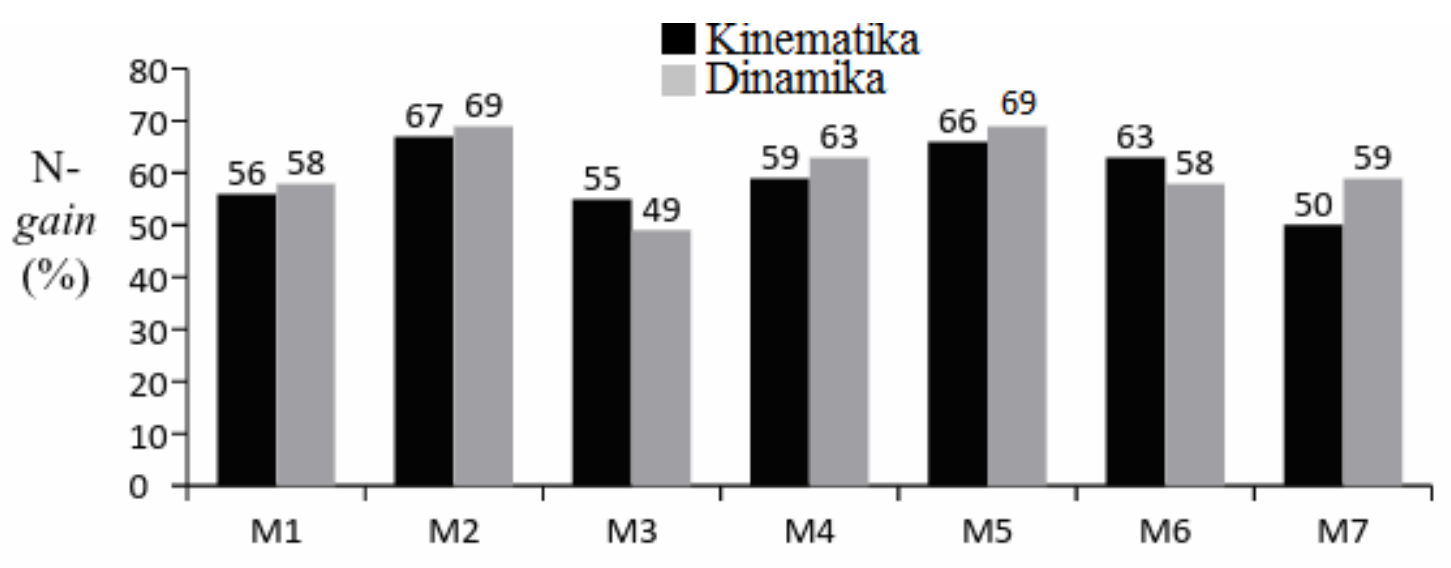

Kemampuan Metakognisi Berdasarkan Indikator Setiap Komponennya

Gambar 1. Perbandingan \%N-gain Metakognisi Berdasarkan Indikator Setiap Komponennya pada Topik Kinematika dan Dinamika Partikel. Indikator M1 = deklarasi, M2 = prosedural, M3 = kondisional, M4 = prediksi, M5 = perencanaan, M6 = pemonitoran dan $\mathrm{M} 7$ = pengevaluasian

Hal ini sejalan dengan Kipnis dan Hofstein (2007) yang menyatakan bahwa pembelajaran problem solving berbasis eksperimen akan melatih dan mengembangkan keterampilan metakognisi khususnya dalam perencanaan karena mahasiswa dipandu untuk dapat merancang apa yang akan dilakukan dan mereka juga didorong untuk berpikir tentang bagaimana tahap-tahap proseduralnya. 


\section{Peningkatan Pemahaman Konsep Fisika dengan Penerapan Model Pembelajaran Problem Solving}

Nilai gain pemahaman konsep pada topik Kinematika Partikel sebesar 57\% dan pada topik Dinamika Partikel 61\%. Secara kuantitas tampak bahwa penerapan model pembelajaran probem solving dapat meningkatkan pemahaman konsep mahasiswa dan termasuk dalam kategori sedang.
Tabel 2. Perbandingan Rerata Skor Tes Awal, Tes Akhir dan \%N-gain Pemahaman Konsep

\begin{tabular}{lcccc}
\hline Topik & $\begin{array}{c}\text { Rerata } \\
\text { skor } \\
\text { tes } \\
\text { awal }\end{array}$ & $\begin{array}{c}\text { Rerata } \\
\text { skor } \\
\text { tes } \\
\text { akhir }\end{array}$ & $\begin{array}{c}\text { N- } \\
\text { gain } \\
(\%)\end{array}$ & $\begin{array}{c}\text { Kate- } \\
\text { gori }\end{array}$ \\
\hline Kinematika & 26,70 & 68,72 & 57 & Sedang \\
\hline Dinamika & 27,94 & 71,54 & 61 & Sedang \\
\hline
\end{tabular}

Ket: Skor maksimum $=100$

Pada Gambar 2 Perbandingan N-gain pemahaman konsep fisika yang dijabarkan dalam indikator dalam setiap aspek pemahaman konsep, yang meliputi menginterpretasi, mencontohkan, membandingkan, mengklasifikasi, menjelaskan, dan menyimpulkan. Berdasarkan Gambar 2, peningkatan N-gain pemahaman konsep.

\section{Kinematika}

Dinamika

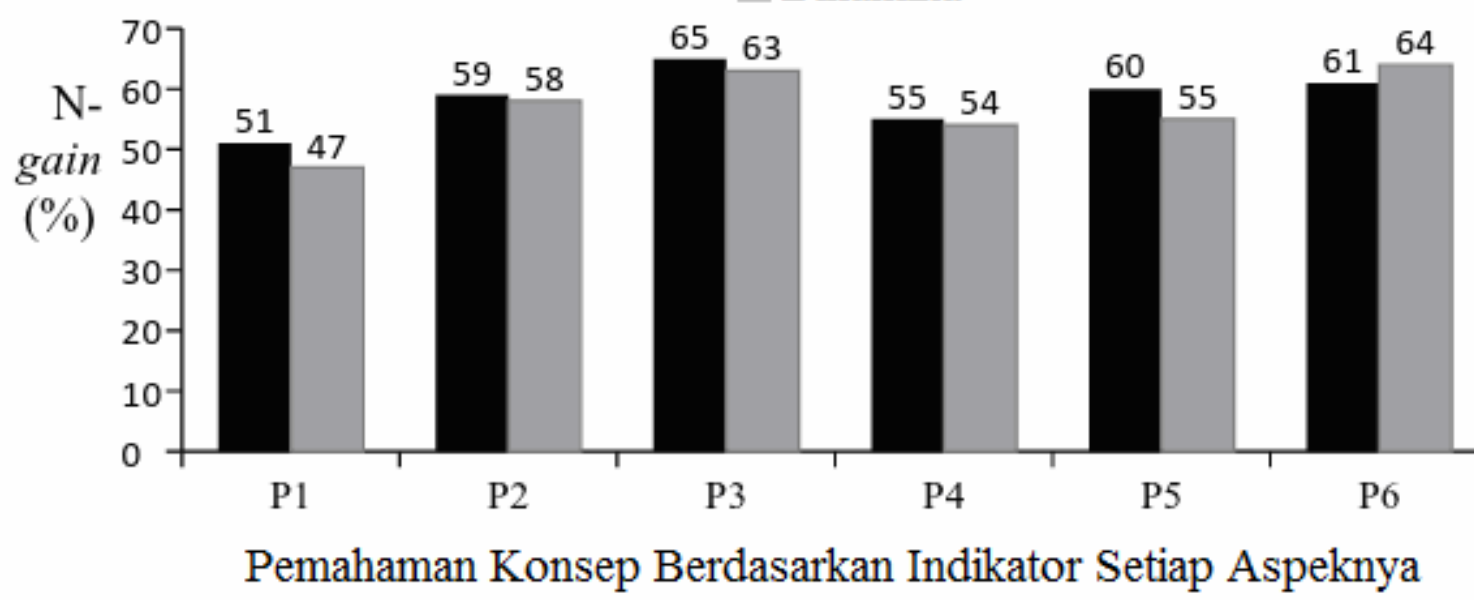

Gambar 2. Perbandingan \%N-gain Pemahaman Konsep Berdasarkan Indikator Setiap Aspeknya pada Topik Kinematika dan Dinamika Partikel. Indikator P1 = menginterpretasi, P2 = mencontohkan, $\mathrm{P} 3$ = membandingkan, $\mathrm{P} 4=$ mengklasifikasikan, $\mathrm{P} 5=$ menjelaskan dan P6 = menyimpulkan

Pada topik Kinematika Partikel untuk setiap indikator menginterpretasi, mencontohkan, membandingkan, mengklasifikasi, menjelaskan, dan menyimpulkan berturut-turut sebesar 51\%, 59\%, 65\%, 55\%, 60\% dan 61\%. Untuk topik Dinamika Partikel, peningkatan $\mathrm{N}$-gain pemahaman konsep untuk setiap indikator menginterpretasi, mencontohkan, membandingkan, mengklasifikasi, menjelaskan, dan menyimpulkan berturut-turut sebesar $47 \%, 58 \%, 63 \%, 54 \%$, 55\% dan 64\%. Berda- sarkan Gambar 2, peningkatan N-gain pemahaman konsep, baik pada topik Kinematika dan Dinamika Partikel paling rendah terjadi pada indikator menginterpretasi, hal ini dapat terjadi karena memang pekerjaan menginterpretasi memiliki tingkat kesulitan yang lebih bila dibandingkan dengan mencontohkan, membandingkan, mengklasifikasi, menjelaskan dan menyimpulkan.

Peningkatan metakognisi, baik pada pada topik Kinematika dan Dinamika Partikel untuk 
kelompok eksperimen dan kelompok kontrol berada pada kategori sedang. Hasil analisis data menunjukkan, apabila ditinjau berdasarkan indikator dalam setiap komponen metakognisi, ternyata N-gain kemampuan metakognisi tertinggi untuk topik Kinematika dan Dinamika Partikel terjadi pada komponen prosedural dan perencanaan dan berada pada kategori tinggi. Hal ini dimungkinkan karena dalam tahaptahap pemecahan masalah melalui eksperimen, mahasiswa dituntut untuk dapat merancang apa yang akan dilakukan dalam penyelidikan. Dalam merancang eksprimen, mahasiswa ditantang dan didorong untuk berpikir tentang setiap tahap prosedural dan tujuan dari masing-masing tahap tersebut. Untuk itu mahasiswa dituntut mempelajari buku-buku dan mengumpulkan informasi dari berbagai sumber lain serta berdiskusi secara kolaboratif tentang ide-ide mereka untuk memecahkan masalah dalam merancang eksperimen. Hal ini sejalan dengan pernyataan Kipnis dan Hofstein (2007), bahwa dengan merancang eksperimen, akan melatih dan mengembangkan keterampilan metakognisi mahasiswa, khususnya dalam perencanaan dan mahasiswa juga didorong untuk berpikir tentang setiap tahap prosedural dan tujuan dari masing-masing tahap tersebut.

Berdasarkan hasil penelitian ini, peningkatan metakognisi diikuti dengan peningkatan pemahaman konsep atau sebaliknya, peningkatan pemahaman konsep juga diikuti dengan peningkatan metakognisi. Peningkatan pemahaman konsep melalui penerapan model pembelajaran problem solving, baik pada pada topik Kinematika dan Dinamika Partikel untuk kelompok eksperimen dan kelompok kontrol berada pada kategori sedang.

Melalui proses pemecahan masalah, mahasiswa lebih mudah mengkonstruksi pengetahuan, menggali ide-ide yang berkaitan dengan konsep-konsep esensial, memperdalam konsep-konsep sehingga ide-ide yang muncul dapat dikembangkan. Hal ini disebabkan karena pengetahuan metakognisi membimbing mahasiswa menyusun lingkungan belajar dan memilih strategi yang tepat, mahasiswa menjadi semakin percaya diri dan menjadi pebelajar yang mandiri, menyadari bahwa mereka dapat memenuhi kebutuhan intelektual sendiri, menemukan banyak informasi oleh tangan mereka sendiri, dan menyadari bahwa disaat mereka menghadapi masalah akan mencoba mencari jalan keluar. Hal ini sesuai dengan Tan (2004) yang menyatakan bahwa dengan penyajian masalah, maka rancangan pemecahan masalah dan tahapannya membantu peserta didik mengembangkan rangkaian hubungan kognitif. Dengan mengumpulkan data dan informasi lebih banyak untuk menyelesaikan masalah, peserta didik menerapkan kemampuan berpikir analitis, seperti merepresentasikan, membandingkan, mengklasifikasikan, dan menyimpulkan. Peserta didik akan menentukan strategi belajarnya serta membandingkannya dan membagi dengan teman lain dalam usaha untuk memecahkan masalah. Kesadaran atas pemikiran sendiri untuk mengarahkan, membandingkan, dan membagi strategi belajarnya menunjukkan bahwa peserta didik terlibat dalam belajar bagaimana belajar, yang menurut Ken Bain (dalam Tan, 2004) akan mengembangkan metakognisinya.

Hal ini didukung oleh Hollingword dan McLoughlin (2002) yang menyatakan bahwa: kemampuan metakognisi yang dimiliki, membimbing mahasiswa menyusun lingkungan belajar dan memilih strategi untuk memperbaiki kinerja kognisi pada masa yang akan datang dan kemampuan metakognisi yang dimiliki dapat meningkatkan hasil belajar, khususnya daya ingat dan pemahaman. Hal ini juga didukung oleh Anderson dan Nashon (2006) yang menyatakan bahwa kemampuan metakognisi yang dimiliki mahasiswa dapat meningkatkan kapasitas belajar yang penuh makna dan membentuk serta mempengaruhi untuk mengkonstruksi pemahaman.

\section{SIMPULAN}

Telah dikembangkan model pembelajaran fisika yang cocok dengan karakteristik ilmu fisika, yang diberi nama model pembe- 
lajaran Fisika Umum berbasis problem solving. Hasil ujicoba terbatas pengembangan model dalam pembelajaran Fisika Umum, didapat bahwa penerapan model pembelajaran Fisika umum berbasis problem solving dapat meningkatkan N-gain metakognisi dan pemahaman konsep pada topik Kinematika dan Dinamika Partikel dalam kategori sedang. Hasil-hasil ini menunjukkan bahwa penerapan model pembelajaran Fisika Umum berbasis problem solving dapat meningkatkan metakognisi dan pemahaman konsep mahasiswa.

\section{DAFTAR PUSTAKA}

Anderson, L. W. \& Krathwohl, D. R. (eds). 2001. A Taxonomy for Learning Teaching and Assessing. A Revision of Bloom's Taxonomy of education Objectives. New York: Addison Wesley.

Anderson, D. \& Nashon, S. 2006. "Predators of Knowledge Construction: Interpreting Students' Metacognition in an Amusement Park Physics Program". Wiley InterScience.

Campbell, J. 2007. "Using Metacogs to Collaborate with Students to Improve Teaching and Learning in Physics". Tersedia http://www.ccfi.educ.ubc.ca/ publication/insight/v11n02/articles/camp bell.html

Desoete, A., Roeyers, H., \& Buysse, A. 2001. "Metacognition and Mathematical Problem Solving in Grade 3". Journal of Learning Disabilities. 34, (5), 435-449.
Hake \& Richard, R. 2002. Relationship of Individual Student Normalized Learning Gains in Mechanics with Gender, HighSchool Physics, and Pretest Scores on Mathematics and Spatial Visualization. Tersedia: http://www.physics.indiana. edu/ hake. [21 September 2008].

Heller, K., \& Heller, P. 1999. Problem-Solving Labs. Introductory Physics I Mechanics. Cooperative Group problem-solving in physics.

Hollingworth, R. \& McLoughlin. 2002. The Development of Metacognitive Skilss among Firts Year Science Student. Tersedia http://fyhe.Qut.Edu.au./FYHEPrevious/Papers/HollingworthPaper.doc.

Kipnis, M., \& Hofstein, A. 2007. "The Inquiry Laboratory as a Source for Development of Metacognitive Skilss". International Journal of Science and Mathematics Education.

Matlin, M. E. 2009. Cognitive Psychology. Seventh Edition. International Student Version. Jhon Wiley \& Sons, Inc.

Tan, O. S. 2004. Enhanching Thinking Problem Based Learning Approached. Singapura: Thomson.

Thiagarajan, S., Semmel, D. S. \& Semmel, M. 1974. Instructional Development for Training Teachers of Exceptional Children. Source Book.

Weinert, F.E., \& Kluwe, R.E. 1987. Metacognition, Motivation and Understanding. London: Lawrence Erbaum Associates. 